\title{
Effects of Lead on Hemopoeitic and Iron Status in Iraqi Workers at Lead Batteries Factory
}

\author{
Fatin F. AL-kazazz* Mustafa H. AL-Waali*
}

Received 2, May, 2012

Accepted 10, July, 2012

\begin{abstract}
:
The present study aimed to evaluate the effect of lead exposure on hemopoetic system (through the index delta-Aminolevulinic acid dehydratase $\delta$-ALAD activity \& hemoglobin concentration $(\mathrm{Hb})$ ) and on iron status (levels of iron Fe, Ferritin Fr, Total iron binding capacity TIBC, percentage of transferine saturation TF\%) in 44 Iraqi worker at lead batteries factory. Workers divided into two groups: smokers $(\mathrm{n}=21)$ mean aged $(37.33 \pm 4.82$ year)and non smokers $(\mathrm{n}=23)$ mean aged(40.78 \pm 7.89 year) and 45 healthy subjects mean aged (33.97 \pm 5.08$)$ as control group . Activity of $\delta$-ALAD ratio shows significant decrease $(\mathrm{p}<0.05)$, while $\mathrm{Hb}$ and hematocrit Hct were non significant $(p>0.05)$ in smoker workers more than non smoker as compared to control. The results show a non significant decrease $(\mathrm{p}>$ 0.05) in the sera levels of iron S.Fe, TS\%, Fr in all workers as compared to control, the amount of decreasing for smoker more than non smoker except ferritin levels. A significant increases in the level of TIBC in workers as compared to control, this elevation is more in smoker than non smoker workers. In smoker workers, there was a significant positive correlation between the blood lead levels BLLs and Hb, Hct,TIBC whereas a significant negative correlation was observed between BLLs and S.Fe, TS\%. In conclusion, the results of this study reveal the importance of monitoring the level of iron status in smoker peoples who dealing or exposure to lead due to the probability injured with anemia and used $\delta$-ALAD ratio to predict the efficiency of their heme synthesis as a new marker for the diagnosis of early stage of anemia.
\end{abstract}

\section{Key Word :lead exposure, $\delta$-ALAD, Iron Status.}

\section{Introduction:}

Lead is a heavy toxic metal to human. It does not have any useful function in the human body, in fact it causes harmful effects when it enters the body either by ingestion, inhalation or by dermal contact (organic lead )[1]. Industry is the major source of lead pollution, particularly in battery factories [2]. The battery manufacturing plant is one of the leading source of occupational lead poisoning in which workers in these plants are easily exposed to lead(3). Lead is related to a broad range of physiological, biochemical, and behavioural change[4]. Lead is toxic not only to the hematopietic system , but also to the gastrointestinal tract, the central and peripheral nervous systems and the kidneys [5]. The main target for lead toxicity is the erythrocytes in which the inhibition of a key enzyme, cytoplasmic $\delta$ - Aminolevulinic acid dehydratase $(\delta-$ ALAD), in heme biosynthesis is one of the major manifestation of acute lead poisoning [6]. $\delta$-ALAD [Porphobilinogen synthetase , (EC4.2.1.24)] is the second enzyme in the heme biosynthetic pathway which catalyzes the condensation of two molecules of

*Chemistry Dep . Scientific of college AL-Mustansiryh unvi . 
ALA to form one molecule of porphobilinogen [7]. $\delta$-ALAD is one of the most sensitive indicators of blood lead accumulation due to exposure[8].

The iron status, of industrial workers occupationally exposed to lead, is particularly important because a substantial evidence supports that iron deficiency not only impairs workers performance but also may increase the absorption and biotoxicity of lead in animals and humans [9]. Although metals such as copper, zinc and iron are essential for human beings , chronic metabolic disturbances may result from an excess or deficiency of these metals [10]. The level of a metal in blood is considered as an index of biologically active metals in the body, reflecting the environmental exposure of population[11].

The aim of this study is to investigate and evaluate the iron status and $\delta$-aminolevulinic acid dehydratase in blood of Iraqi workers in AlWazyria Batteries manufacturing plant and then finding the type of correlation between all iron status index and $\delta$ ALAD activity with blood lead levels.

\section{Materials and Methodes : Subjects:}

A total of forty four males with mean aged (39.13 \pm 6.76$)$ years (range 29-57) year occupationally exposed to lead in battery manufacture for a period of(15-35) years (mean $17.68 \pm 6.99)$ were participated in this study. The workers were divided into two groups: smokers $(n=21)$ and non smokers $(n=23)$. A total of 45 healthy male volunteers mean aged (33.97 \pm 5.08 )years (range 24-45) years served as controls.

\section{Chemical Materials:}

$\mathrm{Na}_{2} \mathrm{HPO}_{4} \cdot 12 \mathrm{H}_{2} \mathrm{O}$, $\mathrm{NaH}_{2} \mathrm{PO}_{4} \cdot 2 \mathrm{H}_{2} \mathrm{O}, \quad \mathrm{CCl}_{3} \mathrm{COOH}$ (TCA) and mercuric chloride $\left(\mathrm{HgCl}_{2}\right)$ from Merck. $\quad \mathrm{ZnCl}_{2}, \quad$ p-dimethyl aminobenzaldehyde

(PDMAB),
Dithiothretol(DTT) and aminolevulinic acid . $\mathrm{HCl}$ (ALA-HCl) from sigma. Hydrochloric acid $(\mathrm{HCl})$ from Riedel de Haen. Iron and Total Iron Binding Capacity(TIBC) Kit from Randox company. Ferritin Kit from Monobind Inc.. Hemoglobin liquid stable reagent from Syrbio comp.

\section{Blood and Biochemical Analysis:}

Blood sample (about $10 \mathrm{ml}$ ) was drown from each individual. The blood sample was divided into three tubes, $2 \mathrm{ml}$ in heparin tube for estimation of $\mathrm{Hb}$, Hct, and enzyme assay. Four milliliter in EDTA tube for lead estimation. The other $4 \mathrm{ml}$ of blood was left for short time to allow blood to clot, then clear serum sample was obtained by centrifugation at $1500 \mathrm{xg}$ for $5 \mathrm{~min}$ to measure $\mathrm{Fe}$, TIBC and Fr. Measurement of blood $\mathrm{Pb}$ level was carried out by flame atomic absorption spectroscopy (FAAS) [ Buck 210 VGP(USA)][12]. $\mathrm{Hb}$ was assayed by the cyanomethemoglobin method. Hct concentration was measured following centrifugation in a microhematocrit centrifuge 1200F,KokuSAN,Jaban). Serum iron (s.Fe)and TIBC were measured by colorimetric assays using kit supplied by (Randox,UK). Serum ferritin (Fr) was measured by the ELISA method . Percentage of transferring saturation (TS\%) was calculated by dividing s.Fe by TIBC and multiplying by 100 . Erythrocyte $\delta$-ALAD activity was estimated by a new modified colorimetric method by Gultepe et al (2009)[13] where erythrocyte ALAD acts an ALA to form porphobilinogen (PBG) which further reacts with regular Erilch's reagent to form a pink colored compound which can be measured using spectrophotometer at (555nm). Hg-TCA solution stops the reaction by precipitating the proteins. The erythrocyte ALAD activity activated by zinc chloride and DTT 
was also measured and the ratio of activated versus non-activated ALAD was determined

\section{Statistical analysis :}

All data were expressed as mean \pm standard deviation (mean \pm SD) . Statistical analysis was performed using LSD considering $\mathrm{p}<$ 0.05 as the lowest limit of significance. Also software program SPSS 16.0 for windows USA, Student t-test, and correlation analysis were used.

\section{Results:}

Table (1): Mean value of age, duration of exposure, BLLs, $\delta$-ALAD activities, $H b$ and Hct for both workers and control group.

\begin{tabular}{|l|c|c|c|c|c|}
\hline \multirow{2}{*}{ Groups description } & \multicolumn{2}{|c|}{$\begin{array}{c}\text { Smoker } \\
\mathrm{n}=21\end{array}$} & \multicolumn{2}{c|}{$\begin{array}{c}\text { Non-smoker } \\
\mathrm{n}=23\end{array}$} & $\begin{array}{c}\text { Control } \\
\mathrm{n}=45\end{array}$ \\
\cline { 2 - 6 } & Mean $\pm \mathrm{SD}$ & P-value & Mean \pm SD & P-value & Mean \pm SD \\
\hline Age (year) & $37.97 \pm 4.82$ & - & $40.78 \pm 7.89$ & - & $33.97 \pm 5.08$ \\
\hline $\begin{array}{l}\text { Duration of } \\
\text { exposure(year) }\end{array}$ & $15.76 \pm 4.10$ & - & $19.43 \pm 8.57$ & - & - \\
\hline $\begin{array}{l}\text { Blood lead level } \\
\text { BLL }(\mu \mathrm{g} / \mathrm{dl})\end{array}$ & $26.57 \pm 5.24$ & 0.0001 & $24.73 \pm 4.49$ & 0.0001 & $16.64 \pm 1.88$ \\
\hline$\delta$-ALAD ratio & $0.262 \pm 0.067$ & 0.05 & $0.310 \pm 0.089$ & N.S & $0.316 \pm 0.116$ \\
\hline Hemoglobin(g/dl) & $14.78 \pm 1.37$ & N.S & $14.11 \pm 2.04$ & N.S & $14.29 \pm 1.59$ \\
\hline Hematocrit $(\%)$ & $44.30 \pm 4.10$ & N.S & $42.78 \pm 7.24$ & N.S & $42.86 \pm 4.77$ \\
\hline
\end{tabular}

$N . S=$ non significant

As shown in Table (1), the differences of exposure duration were non significant for smokers $(15.76 \pm 4.10$ year $)$ and non smokers $(19.43 \pm 8.37$ year $)$. The mean \pm SD BLLs in smokers $(26.57 \pm 5.24 \mu \mathrm{g} / \mathrm{dl})$ and non-smokers $(24.73 \pm 4.49 \mu \mathrm{g} / \mathrm{dl})$ were significantly $(\mathrm{p}$ $<0.000)$ increase as compared with that of control group. The ratio of $\delta$ -
ALAD activity was significantly decreased in smoker $(0.262 \pm 0.067)$ and non significant decrease in non smoker $(0.310 \pm 0.089)$ as compared with that of control group. Non significant differences were observed in $\mathrm{Hb}$ and $\mathrm{Hct}$ for lead exposed workers but slightly increase in the smokers group and decrease in the non smokers

group.

Table (2): Mean value of S.Fe, TIBC, TS\% and Fr for both lead workers and control group.

\begin{tabular}{|c|c|c|c|c|c|}
\hline Groups description & \multicolumn{2}{|c|}{$\begin{array}{c}\text { Smoker } \\
\mathrm{n}=21\end{array}$} & \multicolumn{2}{c|}{$\begin{array}{c}\text { Non-smoker } \\
\mathrm{n}=23\end{array}$} & $\begin{array}{c}\text { Control } \\
\mathrm{n}=45\end{array}$ \\
\cline { 2 - 6 } & Mean \pm SD & P-value & Mean \pm SD & P-value & Mean \pm SD \\
\hline $\begin{array}{c}\text { Serum iron(S.Fe) } \\
(\mu \mathrm{g} / \mathrm{dl})\end{array}$ & $75.23 \pm 23.80$ & N.S & $76.43 \pm 29.76$ & N.S & $88.22 \pm 30.67$ \\
\hline TIBC $(\mu \mathrm{g} / \mathrm{dl})$ & $542.2 \pm 161.6$ & N.S & $478.6 \pm 196.7$ & $>0.0001$ & $421.8 \pm 117.6$ \\
\hline TS \% & $16.54 \pm 11.90$ & N.S & $18.95 \pm 13.68$ & $>0.05$ & $22.52 \pm 9.59$ \\
\hline $\begin{array}{c}\text { Serum ferritin (Fr) } \\
(\mathrm{ng} / \mathrm{dl})\end{array}$ & $102.1 \pm 76.4$ & N.S & $92.60 \pm 55.67$ & N.S & $114.0 \pm 88.03$ \\
\hline
\end{tabular}

$N . S=$ non significant 
From Table (2), the mean \pm SD serum iron levels of smokers $(73.23 \pm 23.80 \mu \mathrm{g} / \mathrm{dl})$ and non smokers $(76.43 \pm 29.36 \mu \mathrm{g} / \mathrm{dl})$ show non significant decrease as compared with control group. The mean \pm SD serum TIBC for non smokers ( $478.61 \pm 196.73$ ) was significantly increased while that of smokers (542.24 \pm 161.62$)$ show non significant increase as compared with that of control group. In comparison with control group, TS\% was significantly decreased in non smokers $(18.95 \pm 13.88)$ and non significant for smokers group $(16.54 \pm 11.90)$. Non significant differences of serum ferritin were found for smoker $(102.10 \pm 76.42)$ and non smokers $(92.60 \pm 55.67)$ as compared with that of control.

Table (3) shows the results analysis of correlation between BLLs and iron status index ( represent by s.Fe, TIBC, TS, Fr) of workers. A significant positive correlation was noticed with $\mathrm{Hb}(\mathrm{r}=0.441, \mathrm{p}=0.045)$, Hct $(r=0.440, p=0.046), \quad \operatorname{TIBC}(r=$ $0.458, \mathrm{p}=0.037)$, while a highly significant negative correlation was observed with s.Fe $(\mathrm{r}=-0.545, \mathrm{p}=$ $0.011)$ and $\mathrm{TS} \%(\mathrm{r}=-0.663, \mathrm{p}=0.001)$ for smoker workers. $\delta$ - ALAD ratio for non smokers shows no correlation or non significant correlation between BLLs with all other parameters under this study.

Table(3):Correlation coefficients and the significant levels of BLLs with different parameters, hemoglobin and components of iron status in lead workers

\begin{tabular}{|c|c|c|c|c|}
\hline $\begin{array}{c}\text { BLL } \\
V s \\
\text { The parameter }\end{array}$ & \multicolumn{2}{|c|}{ Smoker } & \multicolumn{2}{c|}{ Non smoker } \\
\hline & $\mathrm{r}$ & P-value & $\mathrm{r}$ & P-value \\
\hline $\mathrm{Hb}$ & 0.441 & 0.045 & -0.267 & 0.267 \\
\hline $\mathrm{Hct}$ & 0.440 & 0.046 & -0.291 & 0.178 \\
\hline $\mathrm{s} . \mathrm{Fe}$ & -0.545 & 0.011 & 0.267 & 0.218 \\
\hline TIBC & 0.458 & 0.037 & 0.076 & 0.732 \\
\hline $\mathrm{TS} \%$ & -0.663 & 0.001 & -0.005 & 0.981 \\
\hline Fr & 0.174 & 0.453 & 0.079 & 0.720 \\
\hline
\end{tabular}




\section{Discussion:}

The results of this study establish significant increase in mean BLL of the workers group as compared with that of control group. The smoker workers have more BLLs than non smokers in spite that the duration of exposure of the smoker workers is less than that for non smoker workers. This finding is consistent with reports from other Iraqi studies by Mehdi et al (2000) and Bassim (2005)[2,14], they found that BLLs of smokers were increased more than that of non smokers. Smoking affects the BLL at work due to increase hand to mouth movements especially they did not use protective masks. Also tobacco plants may invariably contain certain amonts of lead absorbed from the soil $[15,16]$.Furthermore the mean of exposure duration of the workers in this study was more than 15 years.

The ratio of $\delta$-ALAD activity, which is highly sensitive and specific for lead exposure, can be used to diagnose lead exposed individual [13]. In the present study, the mean ratio of $\delta$-ALAD was non significantly decreased in workers as compared with control groups. This result indicates that lead inhibits the activity of $\delta$ ALAD for these workers. $\delta$-ALAD is usually reduced to $50 \%$ or less from its normal activity when blood lead values are in the range 30-50 $\mu \mathrm{g} / \mathrm{dl}$ [17]. At the molecular level, lead displaces zinc ion at the metal binding site, not the active site, producing inhibition through changing the enzyme's quaternary structure[18]. Decreased $\delta$ ALAD activity caused by lead can be reversed by adding Zn or DTT or by heating[19].

Lead affects the hematopoietic system through reduction of hemoglobin synthesis, but this occurs only with high levels of exposure. $\mathrm{Hb}$ and Hct for non smoker was slightly decreased. It might be due to decreased heme and globin synthesis, or erythrocyte formation and function. Erythrocyte survival also decreased by lead due to inhibition of membrane $\mathrm{Na}^{+}$ / $\mathrm{K}^{+}$ATPase activity[20]. Smokers $\mathrm{Hb}$ and Hct levels were slightly increased. It may be due to smoking effects whereas $\mathrm{CO}$ binds hemoglobin 250 times more than $\mathrm{O}_{2}$ producing carboxy hemoglobin which produces hypoxia and this will accelerate the erythropoiesis [21].

Iron is an essential element which plays a critical role in the heme synthesis pathway. s.Fe, TIBC, TS\% and Fr levels used clinically to evaluate the Iron status . The lower iron status of workers exposed to lead could be attributable to higher BLL or lower dietary iron intake[ 9]. Although many studies reported that low iron status cause a higher absorption of lead in the gastrointestinal tract resulting in higher BLLs[22,23], and the theoretical basis for this observation, is that iron extraction from the diet is small and limited, as human have no physiological pathway for Fe excretion. Duodenal enterocytes are responsible for iron absorption. Iron is transferred across the apical membrane of the enerocyte into the cell using a protein named divalent metal transporter 1(DMT1). DMT1 is not specific for iron ; it can transport a wide variety of divalent metal ions, including $\mathrm{Cu}, \mathrm{Zn}$ and $\mathrm{Pb}$. Therefore if the iron content of the diet is low the other divalent metal ions may be absorbed instead including trace quantities of lead[24,25]

In a previous study [13], $\delta$-ALAD ratio was examined as a new diagnostic marker for heme synthesis by using the ratio instead of activated values. In Iraq , this is the first study on this enzyme by using a new modified method. For further study and to predict 
whether the value BLLs can be used to avoid any further hematopoietic damage in people exposure to lead correlation of BLLs and $\delta$-ALAD with hemopoietic, iron status parameters may be used From Table (3), concerning smoker workers, we found a good positive correlation between BLLs with $\mathrm{Hb}$, Hct and TIBC while a negative correlation between BLLs with s.Fe and $\mathrm{TS} \%$. These correlations represent the direct effect of lead on iron status and heme synthesis. Our findings indicate that the increased levels of lead are associated with a reduced iron concentration in smoker peoples, which will impair their heme synthesis pathway.

\section{Conclusion:}

From all mentioned observations, it can be concluded that the decreasing in iron status for the smoker workers exposed to lead may be a beginning for iron deficiency especially their blood lead levels show highly significant increase and the activity of $\delta$-ALAD ratio was significantly decreased.

\section{Reference:}

1. Mohammed IK, Mahdi AA, Raviraja A, Najmul I, Iqpal A,Thuppil V.2008. Oxidative stress in painters exposed to low lead levels. Arh Hig Rada Toksio 159(3):161-169.

2. Mehdi JK, Al-Imara FJM, Al-Suhail AA.2000.Levels of some trace metals and related enzymes in workers at storage-battery factories in Iraq. East. Mediterr. Heal. J., 6(1):76-82.

3. Lormphongs S, Miyashita K, Morioka I, Chalkittiporn C, Miyai N, Yamamota H.2003. Lead exposure and blood lead level of workers in a battery manufacturing plant in Thailand . Ind.l Health, 41(4):348353.
4. Luch A.2010. "Molecular, clinical and environmental toxicology". Birkhauser Verlag .German. pp 378384.

5. Gidlow D.2004. In-depth review- lead toxicity. Occup. Med., 54(2):76-81.

6. Agency for Toxic Substances and Disease Registry (ATSDR). 2007. Toxicological profile for lead. Atlanta : US department of healthand human services, US Government Printing. pp 102-225.

7. Rama Rao VSS.2010."Teatbook of biochemistry". UBS Publishers Distribution Pvt. Ltd. $11^{\text {th }}$ ed.India. pp 489-494.

8. Kasuba V, Rozgaj R, Milic M, Zeljezic D, Kopjar N, Pizent A, KljakovicGaspic Z. 2010. Evaluation of lead exposure in battery manufacturing workers with focus on different biomarkers. J.Appl. Toxicol.,30(4):321-328.

9. Kim HS, Lee SS, Hwangbo Y, Ahn KD, Lee BK.2003. Cross-sectional study of blood lead effects on iron status in Korean lead workers. Nutrition, 19(7):571-576.

10. Raghunath R, Tripathi RM, Vinod KA, Sathe AP, Khandekar RN, Nambi KSV.1999. Assessment of $\mathrm{Pb}$ $, \mathrm{Cd}, \mathrm{Cu}$ and $\mathrm{Zn}$ exposure of 6-10 years old children in Mumbai .Environ. Res. 80(A):215-221.

11. Tripathi RM, Raighunath R, Mahapatra S, Sadasivan S.2001. Blood lead and its effect on $\mathrm{Cd}, \mathrm{Cu}, \mathrm{Zn}, \mathrm{Fe}$ and hemoglobin levels of children. Sci Total Environ., 277(3):161-168.

12. Haswell SI. 1991."Atomic Absorption Spectrometry :theory, design and application". Elsevier science publishing company Inc. $1^{\text {st }}$ ed. Netherlands .pp 372-373.

13. Gultepe M, Kayadibi H, Bolat B.2009. Reference value for the ALAD enzyme activity ratio in men based on the improvement of each analytical step of the colorimetric 
method and the active/ non active lead concept. Turk. J. Med. Sci. 39(5):775-781.

14. Mohammed BA.2005. Assessment of lead poisoning and bio-effects for workers in Iraqi general company of batteries industry. Thesis. AlMustansriya university.

15. Chuang HY, Lee MT, Chao KY, Wang I, Hu H.1999. Relationship of blood lead levels to personal hygiene habits in lead battery workers: Taiwan, 1991-1997. Am. J. Ind. Med., 35(6):595-603.

16. Hsu PC, Chang HY, Guo YL, Liu YC, Shih TS.2009. Effect of smoking on blood lead levels in workers and role of reactive oxygen species in lead-induced sperm chromatin DNA damage.

Fertility\&Steritlity,91(4):1096-1103.

17. Dongre NN, Suryakar AN, Patial AS, Ambekar JG, Rathi DB.2011. Biochemical effects of lead exposure on systolic \&diastolic blood pressure, heme biosynthesis and hematological parameters in automobile workers of North Karnataka (India).Ind. J. Clin. Biochem.26(4):400-406.

18. Kelada SN, Shelton E, Kaufman RB, Khoury MJ.2001. $\delta$-Aminolevulinic acid dehydratase genotype and lead toxicity: A HuGE review. Am. J. Epidemiol. 154(1):1-13.
19. Sakai T, Yanagihara S, Ushio K.1980. Restoration of lead inhibited $\delta$-ALAD activity in whole blood by heat, zinc ion and (or) dithiothretol. Clin. Chem., 26(5):625-628.

20. .Dongre NN, Suryakar AN, Patial AS, Rathi DB.2010. Biochemical effects of lead exposure to workers in small scale automobile workshops of North Karnataka (India). J. Env. Health Res. 10(1):27-34.

21. Tomei G, Ciarrocca M, Capozzella A, Fiaschetti M, Tomao E, et al.2008. Hemopoietic system in traffic police exposed to urban stressors. Industrial Health, 46(3):298-301.

22. Barton JC, Conrad ME, Nuby S, Harrison L.1978. Effects of iron on the absorption and retention of lead . J. Lab. Clin. Med., 92(2):536.

23. Watson WS, Morrison J, Bethel MIF, et al.1986. Food iron and lead absorption in humans. Am. J. Clin. Nutr., 44(2):248-256.

24. ALAbdulla H, Bareford D, Braithwaite R,Chipman K.2005. Blood lead levels in iron-deficient and non iron-deficient adults. Clin. Lab. Haem., 27(2):105-109.

25. Keramati MR, Sadeghian MH, Mood M. 2010. Correlation between iron deficiency and lead intoxication in the workers of a car battery plant. Int.J.Haem.\& Onc. 20(3): 169-174. 


\section{تأثير الرصاص على تكوين النسيج الاموي وصورة الحديد للعمال العراقيين في

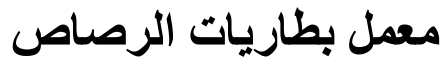 \\ مصطفى حضيري الوائلي

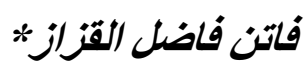

* الجامعة المستنصرية /كلية العلوم/قسم الكيمياء

تهلفة: الدراسة الحالية التحري عن ثأثير التعرض لفلز الرصاص على تكوين النسيج الدموي (من خلال

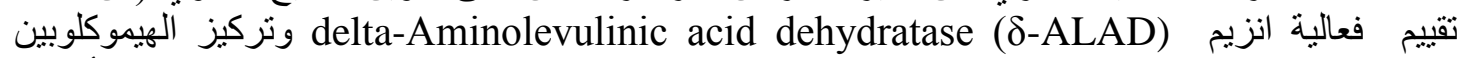

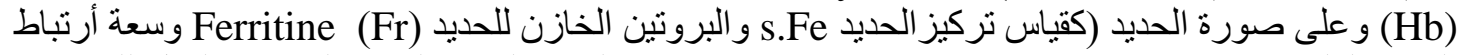

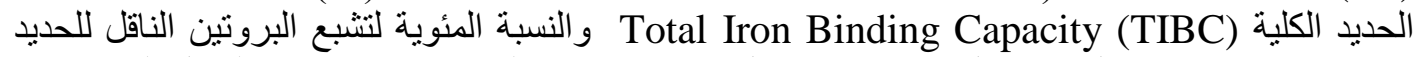
ل44ansferrin(TS\%)

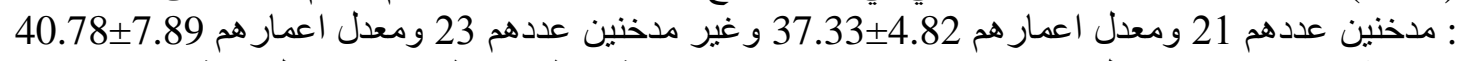

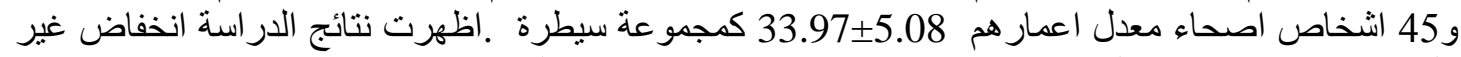

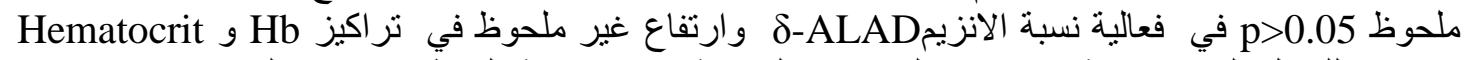

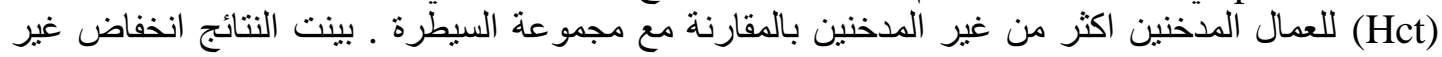

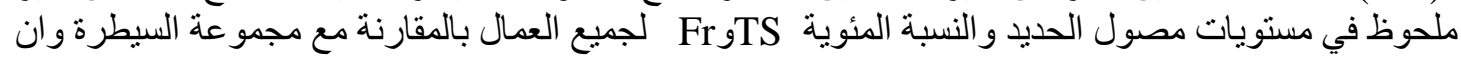

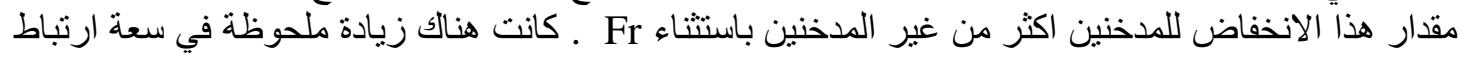

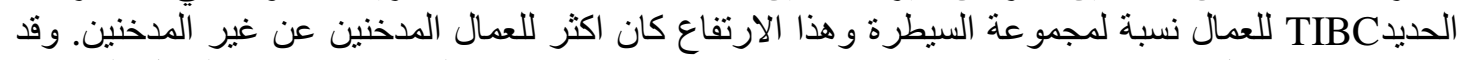

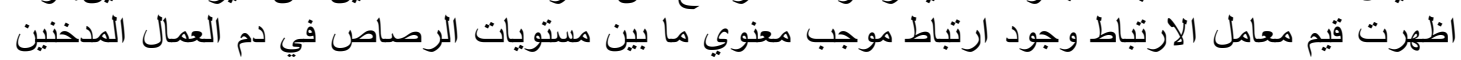

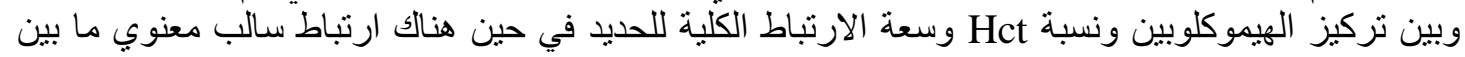

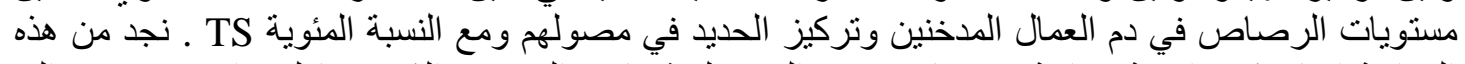

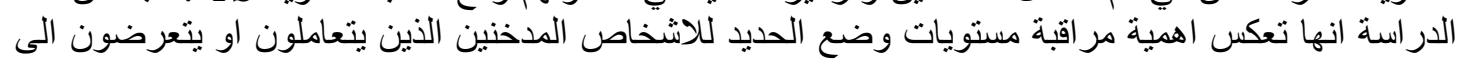

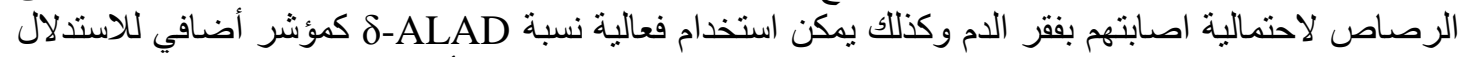
على كفاءة تخليق الهيم وكدالة جديدة لتشخيص الاصنية لاصنية بفقر الدم في مر احله الأولى . 